\title{
Genetic and environmental sources of egg size variation in the butterfly Bicyclus anynana
}

\author{
K Fischer ${ }^{1}$, ANM Bot, BJ Zwaan and PM Brakefield \\ Institute of Biology, Leiden University, PO Box 9516, Leiden NL-2300 RA, The Netherlands
}

By dividing families of the tropical butterfly, Bicyclus anynana, among different larval (including early pupal) and adult (including late pupal) temperatures, we investigate the genetic and environmental effects on egg size. Both sources of variation affected egg size to similar extents. As previously found in other arthropods, egg size tended to increase at lower temperatures. Our data suggest that the plastic response in egg size can be induced during the pupal stage. Females reared as larvae at the same high temperature tended to lay larger eggs when transferred to a lower temperature, either as prepupae or pupae, compared to those remaining at the high temperature. Additionally, females reared as larvae at different temperatures, but maintained at the same temperature from the early pupal stage onwards, laid larger eggs after larval growth at a low temperature. Heritability estimates for egg size were about 0.4 (parent-offspring regression) and 0.2 (variance component estimates using the full-sib families). Although there seemed to be some variation in the plastic response to temperature among families, genotype-environment interactions were nonsignificant.

Heredity (2004) 92, 163-169, advance online publication, 14 January 2004; doi:10.1038/sj.hdy.6800382

Keywords: heritability; offspring size; phenotypic plasticity; reaction norm; temperature

\section{Introduction}

Phenotypic variation in life-history traits observed among individuals or populations of the same species can be a consequence of genetic differentiation, or may be due to the effects of different environments on the expression of the phenotype (Schmalhausen, 1949; Endler, 1986). The latter source of variation may be merely a biochemical or physiological interaction of the organism with its environment, or may be adaptive if phenotypic variation increases fitness in the environments encountered (Schmalhausen, 1949; Stearns, 1989). A comprehensive and synthetic understanding of variation requires the examination of both environmental and genetic sources, as well as their interaction (Bernardo, 1993; Sinervo and Svensson, 1998; Niewiarowski, 2001).

A particularly important and widespread mediator of phenotypic variation in ectothermic animals is temperature. The thermal environment experienced by an individual during development has a direct effect on final size, with body size generally increasing as temperature decreases and vice versa (Atkinson, 1994; Partridge and French, 1996; Chown and Gaston, 1999). Moreover, evolutionary responses, with larger individuals in low-temperature environments, have been found in the wild (latitudinal and altitudinal size clines; eg Imasheva et al, 1994; James et al, 1997; Billerbeck et al, 2000) and in the laboratory (Partridge et al, 1994, 1995). Likewise, egg size in ectotherms was commonly found to increase in colder regions and colder seasons (Azevedo

Correspondence: K Fischer. Institute of Biology, Leiden University, PO Box 9516, Leiden NL-2300 RA, The Netherlands

${ }^{1}$ Current address: Department of Animal Ecology I, Bayreuth University, PO Box 101 251, Bayreuth D-95440, Germany.

E-mail: klaus.fischer@uni-bayreuth.de

Received: 16 January 2003; accepted: 6 October 2003 et al, 1996; Yampolski and Scheiner, 1996; Blanckenhorn, 2000), and insects lay larger eggs at lower temperatures under laboratory conditions (eg Avelar, 1993; Crill et al, 1996; Sheader, 1996; Ernsting and Isaaks, 1997; Blanckenhorn, 2000). The underlying mechanisms shaping this temperature-size rule as well as its adaptive significance are largely unknown (Azevedo et al, 1996; Crill et al, 1996; Blanckenhorn, 2000; Fox and Czesak, 2000).

For the tropical nymphalid butterfly Bicyclus anynana (Butler, 1879), a previous study showed that the prevailing temperature during oviposition induces a plastic response in egg size, with females kept at a lower oviposition temperature laying larger but fewer eggs than those kept at a higher temperature (Fischer et al, in press). By cross-transferring the experimentally manipulated eggs between temperatures, we showed that the larger eggs produced at a lower temperature had a higher hatching success and yielded larger hatchlings with a slightly higher probability of reaching maturity compared to the smaller eggs produced at a higher temperature. Overall, the lower temperature was slightly more detrimental for smaller than for larger eggs. The slight differences in survival across temperatures together with more substantial ones in fecundity indicate that it could pay off to produce fewer but larger offspring (with increased fitness) at a lower temperature, but more and smaller offspring at a higher temperature where the offspring survival was generally high.

This is in agreement with predictions based on theory (Yampolski and Scheiner, 1996). If this were indeed the case and if, in consequence, the temperature-mediated plasticity in egg size were adaptive (in this species), one might expect that there is genetic variation in the plastic response to temperature for natural selection to act upon (as long as the variation has not been completely eroded; Via and Lande, 1985; Scheiner, 1993). 
To address this issue, we use here a full-sib design with sibs being divided between different larval and pupal/egg-laying temperatures, enabling us to draw on several of the questions raised above. First, we will investigate the genetic (family) and environmental (temperature) effects on egg size, as well as potential interactions between the two. The latter would be indicative of the existence of genetic variation in the plastic response of egg size to temperature, and hence that there is potential for short-term evolutionary change. Second, we will explore the effects of larval (including early pupal) rearing temperature and adult (including late pupal) temperature on egg size. Since plastic responses in egg size can be induced by rearing larvae and maintaining the resulting adults at different temperatures, as well as exclusively by different oviposition temperatures, this experiment will reveal information on the timing and hence the sensitive period for the induction of a plastic response. Third, we will estimate the heritability of egg size by means of variance component estimates (using the full-sib families) and parent-offspring regression.

\section{Material and methods}

\section{Study organism and experimental population}

$B$. anynana is a tropical, fruit-feeding butterfly ranging from southern Africa to Ethiopia (Larsen, 1991). The species exhibits striking phenotypic plasticity (two seasonal morphs), which is thought to function as an adaptation to alternative wet-dry seasonal environments and the associated changes in resting background and predation (Brakefield and Larsen, 1984; Brakefield and Reitsma, 1991; Windig et al, 1994). A laboratory stock population of $B$. anynana was established at Leiden University in 1988 from over 80 gravid females collected at a single locality in Malawi. Several hundred adults are reared in each generation, maintaining high levels of heterozygosity (Saccheri and Bruford, 1993). Butterflies from the stock population were used for this study.

\section{Experimental design}

Butterflies of the parental generation were reared in a climate room at $27^{\circ} \mathrm{C}$, high humidity, and a photoperiod of L12:D12 till pupation. Larvae were fed on young maize plants. On day 2 after pupation, female pupae were randomly divided among low $\left(20^{\circ} \mathrm{C}\right.$, forming group $\mathrm{A})$ and high $\left(27^{\circ} \mathrm{C}\right.$, forming group $\left.\mathrm{B}\right)$ temperatures (with high humidity and L12:D12 throughout). The temperatures chosen are similar to the ones experienced by the butterflies during the dry and wet seasons, respectively, in the field (Brakefield and Mazzotta, 1995; Brakefield and Reitsma, 1991). Following adult eclosion, females were individually marked and mated (at the respective temperature, they were assigned to as pupae) to randomly chosen stock males. In order to account for differences in physiological age, females were given 1 day prior to mating (ie separated from males) at $27^{\circ} \mathrm{C}$, and were then put together with males for 2 days for mating, whereas at $20^{\circ} \mathrm{C}$ females had a premating period of 2 days, followed by 3 days for mating. The use of different premating and mating periods was motivated by the fact that the larval development time is about half as long at $27^{\circ} \mathrm{C}$, as compared to $20^{\circ} \mathrm{C}$.

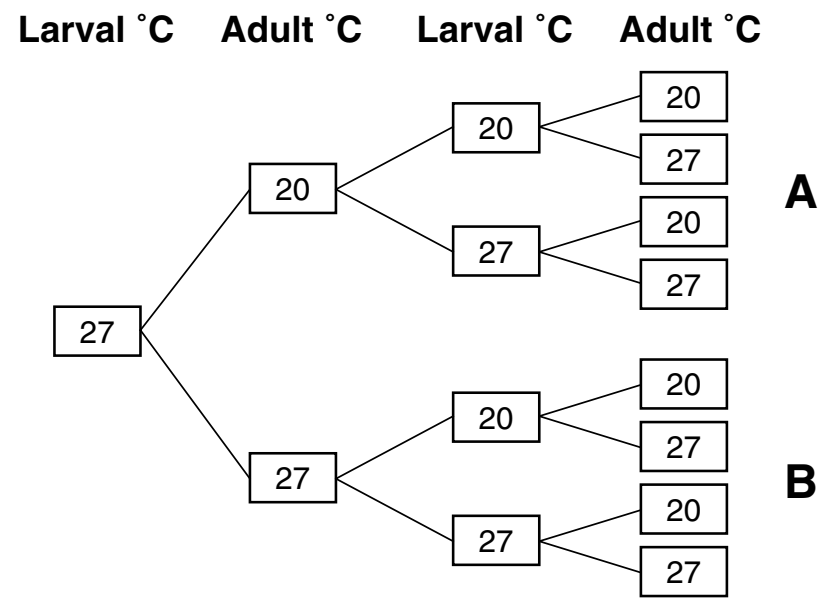

Figure 1 Schematic overview of experimental protocol. Parental generation females were reared as larvae at $27^{\circ} \mathrm{C}$, and on day 2 after pupation randomly divided between 20 and $27^{\circ} \mathrm{C}$. Per female butterfly, two groups of eggs were collected at the respective temperatures they were assigned to, and subsequently divided between 20 and $27^{\circ} \mathrm{C}$ for larval rearing. $\mathrm{F} 1$ generation female pupae were once again divided between 20 and $27^{\circ} \mathrm{C}$, resulting in eight treatment groups with different thermal histories. The offspring of the parental generation females transferred as pupae to 20 or $27^{\circ} \mathrm{C}$ form groups A and B, respectively.

Following mating (ie on days 4 and 6 of adult life at 27 and $20^{\circ} \mathrm{C}$, respectively), females were placed individually in translucent plastic pots (11) containing a fresh cutting of maize to oviposit on. Eggs were collected for 1 $\left(27^{\circ} \mathrm{C}\right)$ and $2\left(20^{\circ} \mathrm{C}\right)$ days, respectively, and subsequently measured (see below). Hence, all eggs included in this analysis were the first ones laid within the females' adult life span, collected within one or two $12 \mathrm{~h}$ light periods, thus effectively controlling for any confounding effects of female age (eg Karlsson and Wiklund, 1984; Brakefield et al, 1994; Braby and Jones, 1995). Over the following days, two groups of eggs were collected per female and again divided between both temperatures for rearing (see Figure 1 for illustration of the experimental design). The offspring was reared in families till pupation, with female pupae afterwards being once again randomly divided between 20 and $27^{\circ} \mathrm{C}$. Division of pupae took place on day 2 after pupation for individuals being reared at $27^{\circ} \mathrm{C}$, and on day 4 for those reared at $20^{\circ} \mathrm{C}$. This design results in eight treatment groups with different thermal histories (ie 20-20-20 for pupal/adult temperature of the mother-larval/pupal temperaturepupal/adult temperature of the daughter, 20-20-27, 20-27-20, 20-27-27, all of which belong to group A; and 27-20-20, 27-20-27, 27-27-20, 27-27-27, belonging to group B). F1 female butterflies were marked, mated and individually set up for egg laying in the way outlined above. Throughout the experiment, butterflies had access to moist banana for adult feeding.

\section{Data collection and analysis}

For all F1 females, we measured pupal mass (measured 1 day after pupation), larval and pupal development time, and egg size. As the eggs of $B$. anynana are nearly perfectly spherical, egg size was measured as the crosssectional area $\left(\mathrm{mm}^{2}\right)$, using a digital camera (Leica 
DC200) connected to a binocular microscope. The resulting images were analysed using Scion Image public software (Scion Corporation, 2000). Tight correlations between egg area (applying image analysis) and egg mass as well as hatchling size confirm that this method is highly reliable to measure egg size in B. anynana (Fischer et al, 2002). The mean of about 10 eggs was used to calculate the egg size for individual females. Previous experiments showed that the means did not change substantially above a critical minimum number of 7-8 eggs (data not shown).

\section{Statistics}

Life-history data were analyzed separately for the offspring of groups A and B (ie for parental generation females transferred as pupae to either 20 or $27^{\circ} \mathrm{C}$ ). This was done to investigate the family effects, and because the larvae reared at $20^{\circ} \mathrm{C}$ had to be divided over two climate cells due to space limitations (ie for $20^{\circ} \mathrm{C}$ larval rearing, the offspring of group A were reared in a different cell than those of group B). Statistical analyses used three-way analyses of variance (ANOVAs) with larval (plus early pupal; hereafter LARVAL) temperature and (late pupal plus) adult (hereafter ADULT) temperature as fixed factors and family as random factor. By removing the nonsignificant interaction terms, the minimum adequate models were constructed. Only those families with at least two offspring in each of the four temperature combination groups were included in the analyses. Heritability of egg size was estimated by means of parent-offspring regression (by regressing the mean egg size of full-sib sisters, weighted by the number of females in each full-sib family, against the mean egg size of the mother) and variance component estimates of the ANOVAs. All statistical tests were performed using JMP version 4.02 .

\section{Results}

\section{Parental generation}

The randomly selected pupae from the stock population, when transferred to either high or low temperature, did not differ in pupal mass $(198.8 \pm 18.8 \mathrm{mg}$ vs $\left.202.2 \pm 14.9 \mathrm{mg} ; t_{56}=0.76, P=0.45\right)$. ADULT temperature had a marginally significant effect on egg size $\left(t_{64}=2.1\right.$, $P=0.04$ ), with females kept at $20^{\circ} \mathrm{C}$ laying larger eggs $\left(0.723 \pm 0.043 \mathrm{~mm}^{2}\right)$ than those at $27^{\circ} \mathrm{C}$ $\left(0.703 \pm 0.034 \mathrm{~mm}^{2}\right)$.

\section{F1 generation}

In both sets of families (ie offspring of groups A and B), genetic (ie families) and environmental (ie LARVAL temperature) sources affected egg size (Tables 1 and 2; Figure 2). Females reared as larvae at $20^{\circ} \mathrm{C}$ laid significantly larger eggs than their sisters at $27^{\circ} \mathrm{C}$ (Table 1). Although there seems to be some variation among families in the plastic response to temperature (Figure 2), this was not substantiated statistically (interaction terms between family and larval temperature, explaining $2-3 \%$ of the variance, were nonsignificant and hence removed from the models presented in Table 2; in the full model, the $P$-values were $P=0.54, \mathrm{~F}_{110}=0.94$ for group $\mathrm{A}$ and $P=0.21, \mathrm{~F}_{1,15}=1.53$ for group $\left.\mathrm{B}\right)$. Different ADULT temperatures, however, did not result in different-sized eggs (Table 1, 2). Significant interactions between LARVAL and ADULT temperature indicate that the effect of ADULT temperature depends on LARVAL temperature. When reared as larvae at $20^{\circ} \mathrm{C}$, egg size tended to increase at the higher rearing temperature, while at $27^{\circ} \mathrm{C}$ the situation is reversed. Family effects explained $19-23 \%\left(h^{2}\right)$ of the total variance in egg size, while temperature effects accounted for 10.1 and $24.4 \%$ in groups A and B, respectively (Table 3). Heritabilities, as estimated by means of parent-offspring regression, reached somewhat higher values with 0.39 and 0.40 for groups A and B, respectively (Table 4 ).

As we have found an effect of ADULT temperature on egg size in the parental, but not in the F1 generation (see above), we repeated this part of the experiment by again dividing randomly chosen stock females of a later generation reared at $27^{\circ} \mathrm{C}$ between 20 and $27^{\circ} \mathrm{C}$. Here, subgroups of females were divided as prepupae, or on days 2 or 4 after pupation between both temperatures. Throughout, the groups transferred as prepupae or pupae to $20^{\circ} \mathrm{C}$ laid larger eggs than the control groups kept at $27^{\circ} \mathrm{C}$ (prepupae: 0.692 vs $0.671 \mathrm{~mm}^{2}, n=13$ each; pupae day 2: 0.693 vs $0.670 \mathrm{~mm}^{2}, n=20$ each; pupae day 4: 0.700 vs $0.670 \mathrm{~mm}^{2}, n=16$ each). A two-way ANOVA confirmed the temperature effect $\left(F_{1,92}=7.8, P=0.006\right)$, whereas neither the timing of division nor its interaction with temperature was significant (time: $F_{2,92}=0.1$, $P=0.91$; interaction term: $\mathrm{F}_{2,92}=0.1, P=0.89$ ).

Regarding the other life-history traits, a significant family effect was only present in the larval development time for the offspring of group A (Table 2). Either high LARVAL or ADULT temperatures caused predictable decreases in development times (Table 1, 2; a marginally significant effect of ADULT temperature on larval

Table 1 Egg size, larval and pupal development times and pupal mass for groups of Bicyclus anynana females with different thermal histories

\begin{tabular}{|c|c|c|c|c|c|c|}
\hline Thermal history & $\mathrm{n}($ fam. $)$ & n (ind.) & Egg size $\left(m^{2}\right)$ & Larval time $(d)$ & Pupal time (d) & Pupal weight (mg) \\
\hline $20-20-20$ & 11 & 45 & $0.712(0.04)$ & $53.2(2.0)$ & $13.1(0.6)$ & 189.9 (19.0) \\
\hline $20-20-27$ & 11 & 52 & $0.733(0.03)$ & $54.7(2.0)$ & $9.5(0.4)$ & $185.6(16.7)$ \\
\hline $20-27-20$ & 11 & 82 & $0.705(0.03)$ & $23.6(0.8)$ & $10.6(0.8)$ & $192.3(8.0)$ \\
\hline $20-27-27$ & 11 & 89 & $0.696(0.02)$ & $23.6(0.7)$ & $6.0(0.1)$ & $192.3(9.2)$ \\
\hline $27-20-20$ & 16 & 75 & $0.742(0.03)$ & 52.5 (2.9) & $13.3(0.6)$ & 179.8 (16.9) \\
\hline $27-20-27$ & 16 & 73 & $0.744(0.03)$ & $54.0(2.9)$ & $9.5(0.3)$ & 175.4 (14.7) \\
\hline $27-27-20$ & 16 & 143 & $0.714(0.03)$ & $22.9(0.8)$ & $10.8(0.4)$ & 199.1 (11.0) \\
\hline $27-27-27$ & 16 & 157 & $0.698(0.03)$ & $22.8(1.0)$ & $6.0(0.1)$ & $198.2(14.0)$ \\
\hline
\end{tabular}

Note that the groups in rows 1-4 and 5-8 represent offspring of the same mothers. Data shown correspond to the mean values of family means for all families with at least two offspring in each of the four treatment groups (SD in parentheses). 'Thermal history' refers to the ADULT temperature of the mother, the LARVAL temperature, and the ADULT temperature of the daughter (see Figure 1). 
Table 2 Results of three-way analyses of variance (ANOVAs) for the effects of family (random factor), LARVAL, and ADULT temperature (fixed) on female life-history traits in Bicyclus anynana

\begin{tabular}{|c|c|c|c|c|c|}
\hline Trait & Source & Sum of squares & $d f$ & F-ratio & $\mathrm{P}$ \\
\hline \multicolumn{6}{|l|}{ (a) } \\
\hline Egg size & Family & 0.122 & 10 & 9.48 & $<0.0001$ \\
\hline \multirow[t]{3}{*}{$R^{2}=0.318$} & Larval $\left({ }^{\circ} \mathrm{C}\right)$ & 0.031 & 1 & 24.16 & $<0.0001$ \\
\hline & Adult $\left({ }^{\circ} \mathrm{C}\right)$ (daughter) & 0.002 & 1 & 1.35 & 0.2458 \\
\hline & Larval $\left({ }^{\circ} \mathrm{C}\right) \times$ adult $\left({ }^{\circ} \mathrm{C}\right)$ & 0.009 & 1 & 6.96 & 0.0089 \\
\hline Larval time & Family & 149.1 & 10 & 2.05 & 0.0289 \\
\hline \multirow[t]{3}{*}{$R^{2}=0.968$} & Larval $\left({ }^{\circ} \mathrm{C}\right)$ & 51290.1 & 1 & 7056.96 & $<0.0001$ \\
\hline & Adult $\left({ }^{\circ} \mathrm{C}\right)$ (daughter) & 37.7 & 1 & 5.18 & 0.0237 \\
\hline & Larval $\left({ }^{\circ} \mathrm{C}\right) \times$ adult $\left({ }^{\circ} \mathrm{C}\right)$ & 36.7 & 1 & 5.04 & 0.0256 \\
\hline Pupal time & Family & 14.87 & 10 & 1.84 & 0.4460 \\
\hline \multirow[t]{6}{*}{$R^{2}=0.961$} & Larval $\left({ }^{\circ} \mathrm{C}\right)$ & 422.85 & 1 & 413.96 & $<0.0001$ \\
\hline & Adult $\left({ }^{\circ} \mathrm{C}\right)$ (daughter) & 807.84 & 1 & 818.37 & $<0.0001$ \\
\hline & Family $\times$ larval $\left({ }^{\circ} \mathrm{C}\right)$ & 11.03 & 10 & 0.81 & 0.6266 \\
\hline & Family $\times$ adult $\left({ }^{\circ} \mathrm{C}\right)$ & 10.65 & 10 & 0.78 & 0.6470 \\
\hline & Larval $\left({ }^{\circ} \mathrm{C}\right) \times$ adult $\left({ }^{\circ} \mathrm{C}\right)$ & 11.71 & 1 & 9.35 & 0.0114 \\
\hline & Family $\times$ larval $\left({ }^{\circ} \mathrm{C}\right) \times$ adult $\left({ }^{\circ} \mathrm{C}\right)$ & 13.61 & 10 & 4.17 & $<0.0001$ \\
\hline Pupal weight & Family & 20560.3 & 10 & 1.81 & 0.1829 \\
\hline \multirow{3}{*}{$R^{2}=0.296$} & Larval $\left({ }^{\circ} \mathrm{C}\right)$ & 1318.9 & 1 & 1.25 & 0.2887 \\
\hline & Adult $\left({ }^{\circ} \mathrm{C}\right)$ (daughter) & 352.1 & 1 & 1.21 & 0.2726 \\
\hline & Family $\times$ larval $\left({ }^{\circ} \mathrm{C}\right)$ & 11380.4 & 10 & 3.91 & $<0.0001$ \\
\hline \multicolumn{6}{|l|}{ (b) } \\
\hline Egg size & Family & 0.214 & 15 & 10.37 & $<0.0001$ \\
\hline \multirow[t]{3}{*}{$R^{2}=0.382$} & Larval $\left({ }^{\circ} \mathrm{C}\right)$ & 0.125 & 1 & 90.72 & $<0.0001$ \\
\hline & Adult $\left({ }^{\circ} \mathrm{C}\right)$ (daughter) & 0.003 & 1 & 2.29 & 0.1312 \\
\hline & Larval $\left({ }^{\circ} \mathrm{C}\right) \times$ adult $\left({ }^{\circ} \mathrm{C}\right)$ & 0.009 & 1 & 6.20 & 0.0132 \\
\hline Larval time & Family & 633.6 & 15 & 1.08 & 0.4444 \\
\hline \multirow[t]{3}{*}{$R^{2}=0.965$} & Larval $\left({ }^{\circ} \mathrm{C}\right)$ & 78487.6 & 1 & 2174.94 & $<0.0001$ \\
\hline & Adult $\left({ }^{\circ} \mathrm{C}\right)$ (daughter) & 9.3 & 1 & 1.16 & 0.2827 \\
\hline & Family $\times$ larval $\left({ }^{\circ} \mathrm{C}\right)$ & 588.7 & 15 & 4.88 & $<0.0001$ \\
\hline Pupal time & Family & 20.6 & 15 & 1.71 & 0.1554 \\
\hline \multirow[t]{4}{*}{$R^{2}=0.958$} & Larval $\left({ }^{\circ} \mathrm{C}\right)$ & 824.9 & 1 & 2417.26 & $<0.0001$ \\
\hline & Adult $\left({ }^{\circ} \mathrm{C}\right)$ (daughter) & 1702.6 & 1 & 2378.12 & $<0.0001$ \\
\hline & Family $\times$ adult $\left({ }^{\circ} \mathrm{C}\right)$ & 12.1 & 15 & 2.35 & 0.0030 \\
\hline & Larval $\left({ }^{\circ} \mathrm{C}\right) \times$ adult $\left({ }^{\circ} \mathrm{C}\right)$ & 18.1 & 1 & 53.13 & $<0.0001$ \\
\hline Pupal weight & Family & 39529.4 & 15 & 6.91 & 0.1517 \\
\hline \multirow[t]{6}{*}{$R^{2}=0.450$} & Larval $\left({ }^{\circ} \mathrm{C}\right)$ & 37003.3 & 1 & 47.79 & $<0.0001$ \\
\hline & Adult $\left({ }^{\circ} \mathrm{C}\right)$ (daughter) & 574.7 & 1 & 2.26 & 0.1481 \\
\hline & Family $\times$ larval $\left({ }^{\circ} \mathrm{C}\right)$ & 12322.0 & 15 & 1.21 & 0.3610 \\
\hline & Family $\times$ adult $\left({ }^{\circ} \mathrm{C}\right)$ & 3620.9 & 15 & 0.35 & 0.9735 \\
\hline & Larval $\left({ }^{\circ} \mathrm{C}\right) \times$ adult $\left({ }^{\circ} \mathrm{C}\right)$ & 259.646 & 1 & 0.40 & 0.5354 \\
\hline & Family $\times$ larval $\left({ }^{\circ} \mathrm{C}\right) \times$ adult $\left({ }^{\circ} \mathrm{C}\right)$ & 10220.6 & 15 & 1.85 & 0.0273 \\
\hline
\end{tabular}

Minimum adequate models were constructed by removing the nonsignificant interaction terms. Significant $P$-values are printed in bold. The two parts of the table refer to the offspring of the parental generation females transferred as pupae to either $20^{\circ} \mathrm{C}$ (a) or $27^{\circ} \mathrm{C}(\mathrm{b}$ ).

development time is presumably a chance effect of allocation to treatments). However, LARVAL temperature did not consistently influence pupal weight; only the offspring within group B attained higher pupal weights when reared at $27^{\circ} \mathrm{C}$. Significant interactions between LARVAL and ADULT temperature for pupal times are caused by the experimental design, as the individuals were divided among temperatures during the pupal stage.

\section{Discussion}

Temperature-mediated plasticity in egg size

As already found in other arthropods (eg Azevedo et al, 1996; Crill et al, 1996; Sheader, 1996; Yampolski and
Scheiner, 1996), egg size increases at a lower temperature in the butterfly B. anynana. Such temperature-induced plasticity that results in larger offspring at lower temperatures seems to be a near universal rule in ectotherms (Azevedo et al, 1996; Yampolski and Scheiner, 1996; Fox and Czesak, 2000). However, as most previous studies did not distinguish between the effects of larval versus adult temperature, much less is known about the sensitive periods for the induction of the plastic response (Fox and Czesak, 2000). Likewise, the underlying mechanisms remain obscure (Azevedo et al, 1996; Blanckenhorn, 2000; Ernsting and Isaaks, 2000; Fox and Czesak, 2000). From previous experiments that disentangled developmental plasticity from acclimation in the adult stage, we do know that low oviposition temperatures result in larger eggs (eg Avelar, 1993; Huey et al, 

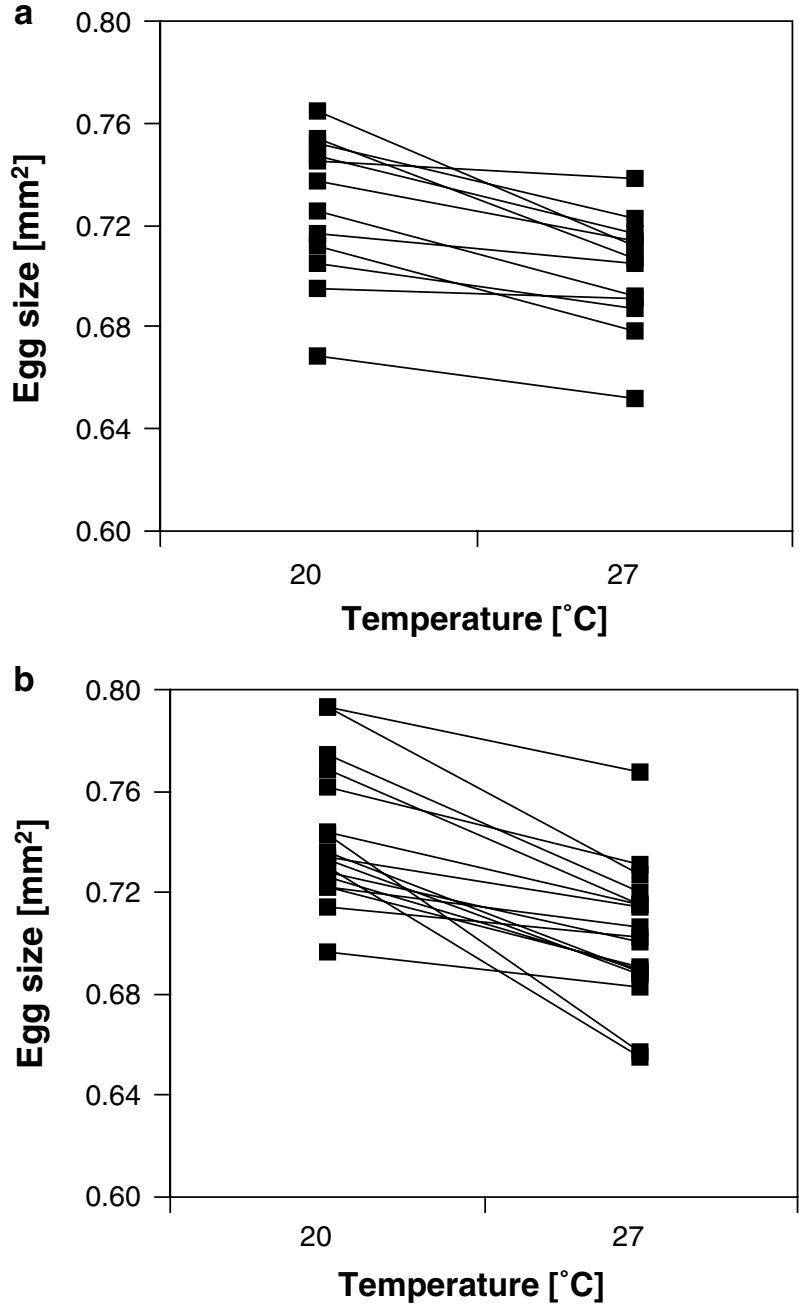

Figure 2 Reaction norms for egg size in relation to LARVAL rearing temperature in the butterfly, Bicyclus anynana. Each line connects the mean egg size of females reared at $20^{\circ} \mathrm{C}$ with the mean egg size of their sisters reared at $27^{\circ} \mathrm{C}$, and thus represents a single split-family. The two graphs refer to parental generation females transferred as pupae to $20^{\circ} \mathrm{C}$ (a) and to $27^{\circ} \mathrm{C}$ (b). As offspring, ADULT temperature did not affect egg size, these treatments were pooled.

Table 3 Proportion (in \%) of the total variance in egg size explained by different sources for the butterfly Bicyclus anynana

\begin{tabular}{lrr}
\hline Component & $A$ & \multicolumn{1}{c}{$B$} \\
\hline Family & 22.7 & 18.6 \\
Larval ${ }^{\circ} \mathrm{C}$ & 10.1 & 24.4 \\
Adult T (daughter) & -2.9 & -1.1 \\
Larval $\left({ }^{\circ} \mathrm{C}\right) \times$ Adult $\left({ }^{\circ} \mathrm{C}\right)$ & 6.3 & 2.9 \\
Residual & 63.8 & 55.2
\end{tabular}

Variance components were estimated using the EMS method of JMP, assuming random effects for all variables (defining LARVAL and ADULT temperature as fixed effects prevents JMP from calculating the necessary variance components). Columns A and B refer to the offspring of the parental generation females, being transferred as pupae to either $20^{\circ} \mathrm{C}$ (group A) or $27^{\circ} \mathrm{C}$ (group B).

1995; Ernsting and Isaaks, 1997; Blanckenhorn, 2000; Fischer et al, in press). However, we could not find a single study investigating exclusively the effects of different temperatures during preadult stages on egg size (by rearing larvae at different temperatures, but maintaining adults in a common environment).

Since egg maturation in butterflies starts in the pupal or early adult phase (eg Boggs, 1997a, b; Ramaswamy et al, 1997), we predicted that lower temperatures experienced from this stage onwards would cause an increase in egg size. This prediction is supported by data from parental generation females and from the additional experiment in which females were transferred to a lower temperature as prepupae, or on days 2 or 4 after pupation. Here, females reared as larvae at $27^{\circ} \mathrm{C}$, but reared as pupae (at least partly) at $20^{\circ} \mathrm{C}$, laid larger eggs than the control groups kept at $27^{\circ} \mathrm{C}$ throughout. However, the results based on the families in the main experiment did not provide similarly conclusive support. Interestingly, for the larvae reared at $27^{\circ} \mathrm{C}$ and divided as pupae among high and low temperatures, there is at least a trend in the predicted direction, whereas this is not the case for the animals reared at $20^{\circ} \mathrm{C}$ (resulting in a significant interaction between LARVAL and ADULT temperature; Tables 1, 2). Consequently, all the evidence in support of our prediction comes from animals reared as larvae at $27^{\circ} \mathrm{C}$, whereas those developing at $20^{\circ} \mathrm{C}$ did not show a clear plastic response (Table 1 ). This could be due to a relatively earlier start of egg maturation (and hence determination of egg size) in these slowly developing animals. Note that, as we used the first eggs laid by individual females in our analysis, we cannot detect any responses to temperature once the size of these early eggs has been determined.

Besides these effects of pupal/adult temperatures on egg size, we have found a clear response to the temperature experienced during larval growth and early pupal development (Table 2). Regardless of late pupal and adult temperature, females reared as larvae at $20^{\circ} \mathrm{C}$ laid larger eggs than their sisters reared at $27^{\circ} \mathrm{C}$. Note that the individuals transferred from 20 to $27^{\circ} \mathrm{C}$ spent ca. 8 days prior to collection of eggs at the higher temperature, and the ones transferred from 27 to $20^{\circ} \mathrm{C}$ about 14 days at the lower temperature. To our knowledge, this, for the first time, shows that temperature differences experienced that early in development induce a plastic response in egg size. These data suggest that the sensitive period for the determination of the size of first eggs largely occurs during the pupal stage. Here, low temperatures during the first days only, as well as from the last days onwards (at least when reared at a high temperature), will result in increased egg size. Once the butterfly had enclosed from the pupa, however, the size of the first eggs seems to be fixed. This is not in contradiction to a response to prevailing temperature conditions during oviposition, as has been found in a number of species (see above). However, this is a gradual process not affecting the very first eggs laid by a given female (Fischer et al, in press and in prep.). These findings are particularly interesting as B. anynana is one of those species not having any chorionated eggs at eclosion (ie egg maturation starts in the early adult stage), and as it is not able to lay any eggs without additional nutrients from adult income (unpublished observations). Note that the differences in egg size found in our study can neither be explained as a correlated response to changes in body size nor as the result of delayed oviposition at lower temperatures (see also Ernsting and Isaaks, 1997; Fox and Czesak, 2000). 
Table 4 Heritability $\left(h^{2} \pm 1\right.$ SE) of egg size in the butterfly Bicyclus anynana

\begin{tabular}{|c|c|c|c|c|c|}
\hline Thermal history & $\mathrm{h}^{2}$ & $\mathrm{R}$ & $\mathrm{P}$ & n (ind.) & $\mathrm{n}($ fam. $)$ \\
\hline $20-20-20$ & $0.297 \pm 0.177$ & 0.400 & 0.0020 & 58 & 17 \\
\hline $20-20-27$ & $0.442 \pm 0.178$ & 0.538 & $<0.0001$ & 58 & 17 \\
\hline $20-27-20$ & $0.398 \pm 0.121$ & 0.636 & $<0.0001$ & 110 & 18 \\
\hline $20-27-27$ & $0.417 \pm 0.083$ & 0.781 & $<0.0001$ & 131 & 18 \\
\hline $27-20-20$ & $0.544 \pm 0.201$ & 0.548 & $<0.0001$ & 78 & 19 \\
\hline $27-20-27$ & $0.371 \pm 0.203$ & 0.387 & 0.0003 & 83 & 21 \\
\hline $27-27-20$ & $0.352 \pm 0.186$ & 0.391 & $<0.0001$ & 176 & 22 \\
\hline $27-27-27$ & $0.314 \pm 0.190$ & 0.347 & $<0.0001$ & 199 & 22 \\
\hline
\end{tabular}

Heritability was estimated by regressing the mean egg size of daughters (weighted by their number) against the mean egg size of the mother. 'Thermal history' refers to the ADULT temperature of the mother, the LARVAL temperature, and the ADULT temperature of the daughter. Note that groups 1-4 and 5-8 represent offspring of the same mothers.

\section{Heritability of egg size and genotype-environment interactions}

The parent-offspring regressions $\left(h^{2}\right.$ ca. 0.4$)$ as well as the variance component estimates $\left(h^{2}\right.$ ca. 0.2$)$ show that heritability of egg size is low to moderate, as could be expected for a life-history trait (Roff, 1997). These values are also in broad agreement with selection experiments using B. anynana, revealing that about $40 \%$ of the variation in egg size is due to additive genetic variance (Fischer et al, unpublished data). Generally, there are surprisingly few data available on genetic variation in egg size within insect populations (Fox and Czesak, 2000). In two seed beetles, egg size is highly heritable and the estimates range between 0.22 and 0.91 , varying between populations and host plants (Fox et al, 1999). Also laboratory selection experiments have demonstrated that egg size is heritable in insects (Harvey, 1983; Schwarzkopf et al, 1999).

Environmental and genetic sources tended to affect egg size to a similar extent, emphasising the importance of considering both types of variation (eg Sinervo and Svensson, 1998; Niewiarowski, 2001). However, we were not able to demonstrate the existence of genotypeenvironment interactions, although there seems to be some variation in the slopes of reaction norms (Figure 2). As heritabilities of plasticity are usually lower than trait heritabilities (Scheiner, 1993; Scheiner and Yampolski, 1998), they are relatively difficult to detect and we cannot rule out that the absence of genetic variation in the plastic response is due to insufficient statistical power (ie small sample sizes) in our analysis. Based on our present data, power analyses indicated that the chance of detecting a significant interaction was only about $6 \%$. The lowest number needed to find a significant interaction at the 5\% level is 2000-3000 individuals. Apart from insufficient statistical power, our negative results may indicate that temperature-mediated egg size plasticity is caused by physiological constraints, or that there is a strong directional selection favoring a direct response to temperature, thus eroding variation in the plastic response. Both interpretations are in line with the fact that the production of bigger eggs at lower temperatures is widespread in insects (see above).

Although temperature-mediated plasticity in egg and body size is a widespread phenomenon (see above), an adjustment of egg size to the prevailing temperature conditions could be of particular importance for tropical B. anynana in its seasonal environment (Fischer et al, in press). Here, reproduction is largely confined to the wet season when oviposition plants are abundantly available, and where 2-3 generations occur. Towards the end of the wet season, however, there is a marked decrease in temperature, starting several weeks before larval food plants dry out completely and reproduction ceases (Windig et al, 1994; Brakefield, 1997). Females ovipositing during this phase may well benefit from laying larger eggs with enhanced fitness.

\section{Pupal weight and development times}

Regarding pupal weight and development time, there was no detectable family effect, with only one exception (larval development time for the offspring of group A). This suggests low heritabilities for these important lifehistory traits (cf. Roff, 1997). The realized heritabilities in B. anynana are indeed low for development time (0.06, Zijlstra et al, unpublished data); however, they are moderate for pupal weight (ca. 0.25, Zwaan et al, unpublished data). The effects of temperature on development time follow the well-known pattern of a faster development at higher temperatures (Honek and Kocourek, 1990). Pupal weight, however, did not increase at lower temperature, comprising an exception from the above-mentioned temperature-size rule (Atkinson, 1994; Partridge and French, 1996). This may indicate that a constant temperature of $20^{\circ} \mathrm{C}$ is already suboptimal for growth and development for this tropical butterfly (Brakefield, 1997).

In summary, this study shows that developmental temperature can induce a plastic response in egg size even at a surprisingly early developmental stage (ie larval plus early pupal), long before first eggs actually mature. Further, our results stress the importance of considering both environmental and genetic sources of variation for this type of trait. However, further research is required to demonstrate whether genetic variation occurs for the plastic response of egg size to temperature.

\section{Acknowledgements}

We thank Casper J Breuker for writing a macro to automate egg measurements, and Niels Wurzer, Bert de Winter and Mariel Lavrijsen for the supply of maize plants. We acknowledge financial support from the German Research Council (DFG grant no. Fi 846/1-1 to KF) and The Netherlands Organization for Scientific Research (NWO 811-34.005 to BJZ). 


\section{References}

Atkinson D (1994). Temperature and organism size - a biological law for ectotherms? Adv Ecol Res 25: 1-58.

Avelar T (1993). Egg size in Drosophila - standard unit of investment or variable response to environment? - the effect of temperature. I Insect Physiol 39: 283-289.

Azevedo RBR, Partridge L, French V (1996). Thermal selection of egg size in Drosophila melanogaster. Evolution 50: 2338-2345.

Bernardo J (1993). Determinants of maturation in animals. Trends Ecol Evol 8: 166-173.

Billerbeck JM, Schultz ET, Conover DO (2000). Adaptive variation in energy acquisition and allocation among latitudinal populations of the Atlantic silverside. Oecologia 122: $210-219$.

Blanckenhorn WU (2000). Temperature effects on egg size and their fitness consequences in the yellow dung fly Scathophaga stercoraria. Evol Ecol 14: 627-643.

Boggs CL (1997a). Reproductive allocation from reserves and income in butterfly species with differing adult diets. Ecology 78: 181-191.

Boggs CL (1997b). Dynamics of reproductive allocation from juvenile and adult feeding: radiotracer studies. Ecology 78: 192-202.

Braby MF, Jones RE (1995). Reproductive patterns and resource allocation in tropical butterflies: influence of adult diet and seasonal phenotype on fecundity, longevity and egg size. Oikos 72: 189-204.

Brakefield PM (1997). Phenotypic plasticity and fluctuating asymmetry as responses to environmental stress in the butterfly Bicyclus anynana. In: Bijlsma RR, Loeschke V (eds) Environmental Stress: Adaptation and Evolution. Birkhäuser: Basel pp 65-78.

Brakefield PM, Kooi RE, den Hollander N, van Alphen WCH (1994). Egg size declines with female age in the fruit-feeding tropical butterfly Bicyclus anynana (Satyrinae). Proc Exp Appl Entomol 5: 53-54.

Brakefield PM, Larsen TB (1984). The evolutionary significance of dry and wet season forms in some tropical butterflies. Biol J Linn Soc 22: 1-12.

Brakefield PM, Mazzotta V (1995). Matching field and laboratory environments: effects of neglecting daily temperature variation on insect reaction norms. J Evol Biol 8: 559-573.

Brakefield PM, Reitsma N (1991). Phenotypic plasticity, seasonal climate and the population biology of Bicyclus butterflies (Satyridae) in Malawi. Ecol Entomol 16: 291-303.

Chown SL, Gaston KJ (1999). Exploring links between physiology and ecology at macro-scales: the role of respiratory metabolism in insects. Biol Rev Camb Philos Soc 74: 87-120.

Crill WD, Huey RB, Gilchrist GW (1996). Within- and betweengeneration effects of temperature on the morphology and physiology of Drosophila melanogaster. Evolution 50: 1205-1218.

Endler JA (1986). Natural Selection in the Wild. University Press: Princeton.

Ernsting G, Isaaks A (1997). Effects of temperature and season on egg size, hatchling size and adult size in Notiophilus biguttatus. Ecol Entomol 22: 32-40.

Ernsting G, Isaaks A (2000). Ectotherms, temperature, and trade-offs: size and number of eggs in a carabid beetle. Am Nat 155: 804-813

Fischer K, Brakefield PM, Zwaan BJ (in press). Plasticity in butterfly egg size: Why larger offspring at lower temperatures? Ecology.

Fischer K, Zwaan BJ, Brakefield PM (2002). How does egg size relate to body size in butterflies? Oecologia 131: 375-379.

Fox CW, Czesak ME (2000). Evolutionary ecology of progeny size in arthropods. Annu Rev Entomol 45: 341-369.

Fox CW, Czesak ME, Mousseau TA, Roff DA (1999). The evolutionary genetics of an adaptive maternal effect: egg size plasticity in a seed beetle. Evolution 53: 552-560.
Harvey GT (1983). Environmental and genetic effects on mean egg weight in spruce budworm (Lepidoptera: Tortricidae). Can Entomol 115: 1109-1117.

Honek A, Kocourek F (1990). Temperature and development time in insects: a general relationship between thermal constants. Zool Jb Syst 117: 401-439.

Huey RB, Wakefield T, Crill WD, Gilchrist WG (1995). Within- and between-generation effects of temperature on early fecundity of Drosophila melanogaster. Heredity $\mathbf{7 4}$ 216-223.

Imasheva AG, Bubli OA, Lazebny OE (1994). Variation in wing length in Eurasian natural populations of Drosophila melanogaster. Heredity 72: 508-514.

James AC, Azevedo RBR, Partridge L (1997). Genetic and environmental responses to temperature of Drosophila melanogaster from a latitudinal cline. Genetics 146: 881-890.

Karlsson B, Wiklund C (1984). Egg weight variation and lack of correlation between egg weight and offspring fitness in the wall brown butterfly, Lasiommata megera. Oikos 43: 376-385.

Larsen TB (1991). The Butterflies of Kenya. University Press: Oxford.

Niewiarowski PH (2001). Energy budgets, growth rates, and thermal constraints: toward an integrative approach to the study of life-history variation. Am Nat 157: 421-433.

Partridge L, Barrie B, Barton NH, Fowler K, French V (1995). Rapid laboratory evolution of adult life history traits in Drosophila melanogaster in response to temperature. Evolution 49: 538-544.

Partridge L, Barrie B, Fowler K, French V (1994). Evolution and development of body size and cell size in Drosophila melanogaster in response to temperature. Evolution 48 1269-1276.

Partridge L, French V (1996). Thermal evolution of ectotherm body size: why get big in the cold?. In: Johnston IA, Bennett AF (eds) Phenotypic and Evolutionary Adaptation. University Press: Cambridge pp 265-292.

Ramaswamy SB, Shu SQ, Park YI, Zeng FR (1997). Dynamics of juvenile hormone-mediated gonadotropism in the Lepidoptera. Arch Insect Biochem 35: 539-558.

Roff DA (1997). Evolutionary Quantitative Genetics. Chapman \& Hall: New York.

Saccheri IJ, Bruford MW (1993). DNA fingerprinting in a butterfly, Bicyclus anynana (Satyridae). I Hered 84: 195-200.

Scheiner SM (1993). Genetics and evolution of phenotypic plasticity. Annu Rev Ecol Syst 24: 35-68.

Scheiner SM, Yampolski LU (1998). The evolution of Daphnia pulex in a temporally varying environment. Genet Res $\mathbf{7 2}$ 25-37.

Schmalhausen II (1949). Factors of Evolution. Blakiston: Philadelphia.

Schwarzkopf L, Blows MW, Caley MJ (1999). Life-history consequences of divergent selection on egg size in Drosophila melanogaster. Am Nat 154: 333-340.

Scion Corporation (2000). Scion Image 402

Sheader M (1996). Factors influencing egg size in the gammarid amphipod Gammarus insensibilis. Mar Biol 124: 519-526.

Sinervo B, Svensson E (1998). Mechanistic and selective causes of life history trade-offs and plasticity. Oikos 83: 432-442.

Stearns SC (1989). The evolutionary significance of phenotypic plasticity. Bioscience 39: 436-445.

Via SM, Lande R (1985). Genotype-environment interaction and the evolution of phenotypic plasticity. Evolution 39: $505-522$.

Windig JJ, Brakefield PM, Reitsma N, Wilson JGM (1994). Seasonal polyphenism in the wild: survey of wing patterns in five species of Bicyclus butterflies in Malawi. Ecol Entomol 19: 285-298.

Yampolski LY, Scheiner SM (1996). Why larger offspring at lower temperatures? A demographic approach. Am Nat 147 86-100. 